\title{
PReS-FINAL-2025: Arthritis associated with human immunodeficiency virus
}

\author{
AE Bean ${ }^{1 *}$, M Al-Obaidi $^{1}$, F Shakley $^{2}$, C Waruiru $^{2}$, D Hawley $^{1}$ \\ From 20th Pediatric Rheumatology European Society (PReS) Congress \\ Ljubljana, Slovenia. 25-29 September 2013
}

\section{Introduction}

There is a clear, documented association between Human Immunodeficiency Virus (HIV) and arthritis in children and young people (CYP). However, this association has not been clearly defined and the arthritis has been seen to resolve with differing management strategies.

\section{Objectives}

- To present a case of a child diagnosed and treated for Juvenile Idiopathic Arthritis (JIA) who was subsequently found to have HIV which led to treatment modification.

- To discuss HIV testing in CYP presenting with arthritis.

- To explore appropriate treatment options in CYP with HIV who have arthritis.

\section{Methods}

We retrospectively reviewed the case record of a fourteen year old boy of African origin with arthritis. He had been previously well and presented with a two week history of initially right ankle swelling which progressed to involve his left knee, right ankle, left wrist and distal interphalangeal joint of his index finger of his left hand. All these joints were swollen, warm and had restricted range of movement. He was systemically well and was diagnosed with polyarticular JIA. Initial management consisted of oral Naproxen, Prednisolone $0.6 \mathrm{mg} / \mathrm{kg}$ and Methotrexate $15 \mathrm{mg} / \mathrm{m}^{2}$.

This treatment resulted in some improvment in his joint symptoms. However, he represented two weeks later experiencing night sweats and was found to have generalised lymphadenopathy. After further history and investigation, he was diagnosed with HIV infection.

${ }^{1}$ Paediatric Rheumatology, Sheffield Children's Hospital, Sheffield, UK Full list of author information is available at the end of the article
He was subsequently referred to tertiary centre specialists in Paediatric Rheumatology and Infectious Diseases/Immunology (at Sheffield Children's Hospital) for further investigation.

\section{Results}

His CD4 count was $295 \times 10^{6} / \mathrm{L}$ and viral load of 8487 copies/ml. Extensive investigation did not reveal another infective cause for his joint symptoms. At presentation his $C$ reactive protein $(C R P)$ was $18 \mathrm{mg} / \mathrm{L}$ and erythrocyte sedimentation rate (ESR) $>145 \mathrm{~mm} / \mathrm{hr}$. Anti-nuclear antibodies and extractable nuclear antigens were negative; double stranded DNA was $160 \mathrm{IU} / \mathrm{ml}$.

Within a multidisciplinary team including specialists in Infectious Diseases and Rheumatology, the current literature was reviewed. He was managed with intra-articular administration of Triamcinolone Hexacetonide into affected joints, and antiretroviral therapy. Two weeks following this he was re-assessed showing complete resolution of his joint signs and symptoms. Inflammatory markers normalised with CRP $<7 \mathrm{mg} / \mathrm{L}$ and ESR $5 \mathrm{~mm} / \mathrm{hr}$.

\section{Conclusion}

This case raises awareness of arthritis as a presenting feature of HIV in CYP. Furthermore, it raises the question of which CYP with JIA should be tested for HIV. It also highlights that more international collaborative work is required to determine optimal treatment strategies for HIV associated arthritis in CYP.

\section{Disclosure of interest}

None declared.

\footnotetext{
Authors' details

'Paediatric Rheumatology, Sheffield Children's Hospital, Sheffield, UK.

${ }^{2}$ Paediatric Infectious Disease and Immunology, Sheffield Chidren's Hospital, Sheffield, UK.
} Attribution License (http://creativecommons.org/licenses/by/2.0), which permits unrestricted use, distribution, and reproduction in any medium, provided the original work is properly cited. The Creative Commons Public Domain Dedication waiver (http:// creativecommons.org/publicdomain/zero/1.0/) applies to the data made available in this article, unless otherwise stated. 
- Convenient online submission

- Thorough peer review

- No space constraints or color figure charges

- Immediate publication on acceptance

- Inclusion in PubMed, CAS, Scopus and Google Scholar

- Research which is freely available for redistribution 